\title{
Business Marketing and Its Transformation with the Insertion of Social Networks
}

\author{
Juanys Chiquillo Rodelo ${ }^{\text {* }}$, Remedios Pitre Redondo' and Hugo G. Hernandez Palma² \\ 1Faculty of Social Work, University of La Guajira; jchiquillo@uniguajira.edu.co, rpitre@uniguajira.edu.co \\ 2Faculty Economics, University of the Atlantico; hugohernandezpalma@gmail.com
}

\begin{abstract}
Objective: This research is being carried out with the aim of analysing the impact of business marketing and its transformation with the arrival of social networks as a mechanism for boosting production areas. Methodology: In order to achieve the defined objective, a qualitative research with descriptive characteristics is proposed, since it will seek to recognize the most outstanding aspects of the changes that social networks have generated for today's companies. Recommendations: The information gathered shows that digital marketing and social networks have made a difference to everything related to business relations and proposes a much more dynamic and innovative scenario in the way of doing business. Conclusion: The contributions compiled in the final part are useful for all types of organizations, since as companies adopt new trends they will be able to lead processes of greater participation in global markets.
\end{abstract}

Keywords: Business, Business Marketing, Competitiveness, Innovation Social Networks

\section{Introduction}

According to figures managed by the Confederation of Chambers of Commerce (Confecamaras), only $74 \%$ of SMEs have access to the Internet, of which $20 \%$ do not yet have a website, $42 \%$ do not use social networks, $50 \%$ have not developed e-commerce plans, and only $39 \%$ have a virtualized tool for managing business relations with their customers ${ }^{1}$. Despite being in a global era, for the vast majority of small and medium enterprises (SMEs), digital marketing strategies are unknown as a key tool for differentiation, productivity and competitiveness, since these types of organizations, although they have characteristics that provide them with greater flexibility for business development, also depend on the strategic vision of an entrepreneur who carries on his shoulders almost all the decisions of the organization, thus limiting the knowledge and application of new marketing methods ${ }^{2}$.

Social networks are defined as places on the Internet where people of different natures publish and share personal and professional information with other people, whether known or unknown'; they are characterized by total or partial anonymity, and synchronous or anachronistic ease of contact, as well as being developed at different levels of security; three essential types have been identified so far as they are: professionals, generalists and specialists ${ }^{4}$; its definition is in accordance with the nature of the interactions between the people who participate in them ${ }^{5}$; the most outstanding are Facebook, YouTube and Twitter, and others that have been reaching great relevance such as Pinterest and LinkedIn; Facebook is the one that has reached the highest number of users, reaching 1.100 million after eight years of creation, it has also been the second most visited page on the Internet ${ }^{6}$.

\section{Methodology}

In order to achieve the defined objective, a qualitative research with descriptive characteristics is proposed, since it will seek to recognize the most outstanding aspects of the changes that social networks have generated for today's companies. Qualitative analysis is characterized by observing the natural behaviors of phenomena, realities, markets or populations ${ }^{\underline{7}}$, which will

*Author for correspondence 
allow us to interpret the influence of social networks on business marketing from a documentary review. On the other hand, the descriptive approach inserts according to the scientific method, the possibility of describing the behaviors without influencing the variables, thus providing the necessary information to expose reflections that can contribute to the deep understanding of events of interest $\stackrel{乛}{-}$. The methodology outlined above is estimated in accordance with the impact to be analyzed, since the level of knowledge expected for the topic can be reached based on research and business publications?

\section{Results}

Marketing involves selection and market analysis, through knowledge of consumer characteristics, as well as the identification and assessment of the possibilities of creating, developing and achieving stability in the marketing mix; this is why it is considered important to outline four of the fundamental aspects in the development of marketing strategies, applicable to traditional and non-traditional media ${ }^{7}$, these elements are shown in Figure 1.

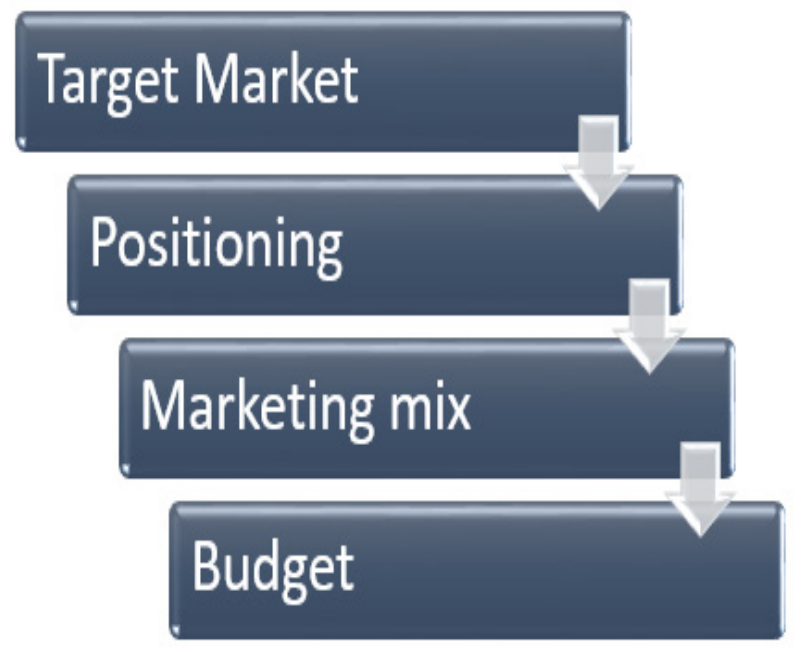

Figure 1. Aspects for marketing strategy.

The factors are described as follows ${ }^{7}$ :

- The target market: made up of a group of people with similar needs who constitute the target market of the company.

- Positioning: seeks to develop offers that are attractive to its consumers compared to those presented by competitors.
- The combination of marketing: or marketing mix, composed by the product, the market, the price and the promotion, in the way these variables are combined, will be the level of the results of acceptance by the customers.

- The determination of marketing expenditure levels: this is about budget planning which should be calculated in such a way that it is considered as desired returns for investors.

Today's marketing has changed, which has introduced new concepts, terms and tools since the emergence of digital marketing, such as organic positioning, Search Engine Optimization (SEO), keywords, inbound, social networks, outbound, SEM or search engine marketing, AdWords, Display Ads, Facebook Ads, among others. All of the above indicates a substantial change in the paradigms established in the interaction of businesses with their actual and potential consumers ${ }^{10}$.

In 2011, Colombia was named the ninth country in Latin America, where e-commerce has developed most in recent years; according to the Colombian Chamber of Electronic Commerce, Colombian buyers number more than 20 million Internet users and is the second fastest growing market in Latin America in terms of percentage growth in e-commerce ${ }^{11}$. With social networking, geography is no longer a communication barrier and anonymity is possible, making self-exposure easier and easier; the community has evolved into a global reach, becoming an environment where people can meet each other around the world, using increasingly diverse forms of interaction ${ }^{12}$.

The introduction of these media into global marketing has transformed customers into more sophisticated consumers $\frac{13}{}$, as they have developed new tactics for searching, evaluating, choosing and purchasing goods and services; recent research reveals a demand for customized products, an increased willingness of customers to actively participate in the product development process, and an increased interest in expressing their opinion at more stages of the business process ${ }^{14}$.

Social media are excellent vehicles for building customer relationships, including the creation of branded fan pages on social networks, where companies post videos, messages, questionnaires, information and other material, from which customers can indicate that they like branding or comment on $\mathrm{it}^{\frac{15}{5}}$. Relevance is the second most important factor affecting brand loyalty, so companies must stay current on their customers' interests, activities 
and current prospects in life $\frac{16}{}$. Finally, the popularity of content among friends also increases consumer brand loyalty; the impact of voice-to-voice in marketing is an aspect to consider, especially in online environments ${ }^{17}$.

Studies have found a positive relationship between the experiences of marketers who adopt social networking as part of their marketing strategies, and the results in sales and brand recognition, as a result, Constantinides $\frac{18}{}$ highlights the following benefits:

- Increased likelihood of customers recommending the company's products or services.

- Improvement in the return on investment in marketing.

- Increase in the customer acquisition rate.

As a result, marketers can use social networks to try to stimulate conversation, encourage interaction, and carry out traditional forms of marketing as well, in order to build brand loyalty 18 . To achieve this, marketers must really engage customers, adopting new technology, limiting the power of bureaucracy, training and investing in their employees, and informing top management about social networking opportunities ${ }^{19}$. In an effort to achieve the greatest possible influence, some factors have been identified, both internal and external, which should be considered and which are detailed below ${ }^{20}$ :

- End Users: The end user has a great influence on the process of technology adoption among SMEs, adequate training allows for an adequate transfer of knowledge and a change of attitude for a positive assimilation of the new tools.

- Organizational: Management will facilitate and streamline the exchange of information, the influence of senior management on the availability of resources ensures that there is enough money, time and human talent to successfully initiate and complete new e-commerce projects, and the awareness and enthusiasm for emerging technologies, the ease with which they are used by managers, and the existence of related experimentation and innovation positively influence adoption.

- Technological: Related studies show that users have become more receptive to the Internet, however, there are still some expectations and concerns about the credibility of the technology when it comes to investing money; additionally, innovation in technology also has a concern about the compatibility of technology on the areas that make up the environment in organizations.

- Administration: The role of management will lead to a higher level of commitment and participation among members and workers in your company and, consequently, greater participation in the adoption of technology; leaders who are positively disposed towards the deployment of e-commerce encourage and support innovations.

- Business Environment: Political influence and government initiatives for adoption, as well as basic infrastructure such as high-speed internet connection, are important aspects of promoting the use of technology. Another important factor is the willingness of the market to use new means of trade, as well as the trends used by competitors and global marketing in general become incentives for the adoption of new tools.

Social network marketing can be very advantageous for businesses, if used correctly, it can help find talent, create brand awareness, find new customers and help drive brand intelligence and market research; some of the advantages identified by some authors are ${ }^{21}$ :

- Brand Intelligence: The main advantage of managing social networks is the amount of information useful for building your customer database, considering trends, customer feedback for product development, loyalty management, and customer segmentation, among others. Unlike other traditional marketing tools, the advantage of this new electronic channel is that it is able to communicate globally and enrich marketing on a personal level.

- Cost Savings: Marketing can be an economical way to promote a business rather than building a large marketing team or a high investment budget.

- Connections: Companies can benefit from social network marketing, since from the databases, they can explore business opportunities; also, they can be an excellent way to find suppliers or employees.

- Brand Awareness: To increase brand awareness, companies should encourage their employees to engage in social marketing activities in order to stay connected to the community.

In addition to the above, it is important to consider the views expressed by the Boston Consulting Group 22 , 
which defines the advantages of social network marketing according to the criteria set out in Figure 2.

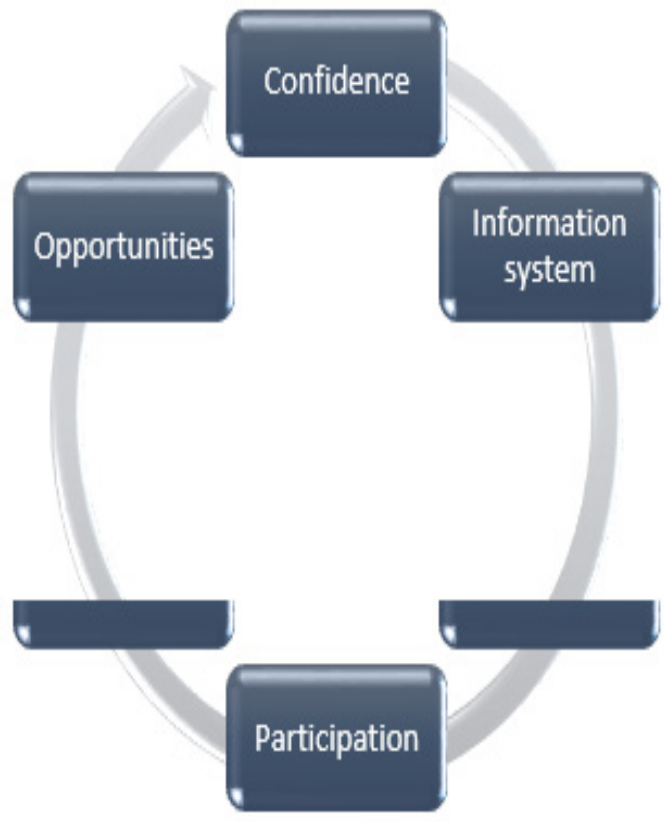

Figure 2. Benefit of using social networks in marketing.

Just as benefits can be obtained from the use of social networks in marketing strategies, care must also be taken to avoid mistakes that can be very harmful in the interaction with customers, which is why experts in the field suggest the following aspects, see Figure 321 .

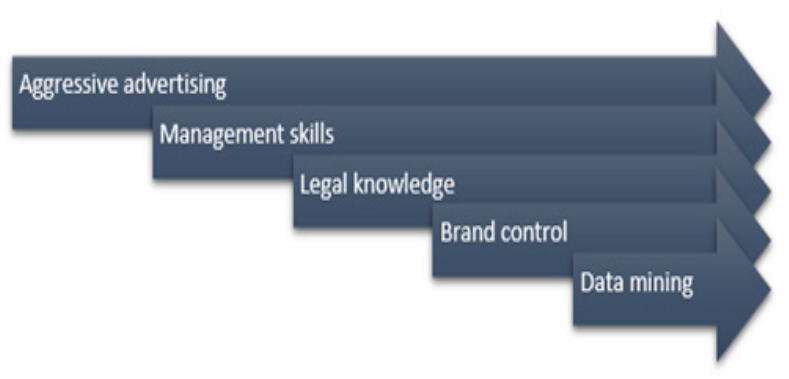

Figure 3. Social network management recommendations.

The aspects illustrated are reviewed as follows ${ }^{21}$ :

- Aggressive Advertising: It can be risky if companies target consumers with ads, promotions and product sales very aggressively, as this can lead to consumers choosing not to stay online:

- Lack of E-Commerce Skills: The use of social networks can be counterproductive if consumers in a particular business sector are unwilling to adopt new technological tools in their purchasing processes.

- Legal Issues: Companies must take special care in market research and advertising laws to avoid crossing legal limits.

- Deficiency in Brand Control: With social networks, consumers can express their experiences with products, services, or customer service, which may prove to be critical, and if not handled properly can generate great harm in the achievements intended by marketing.

- Data Mining: Over time, social network users have become increasingly cautious about sharing their private data, projecting that privacy issues will not allow for easy consumer access to private data.

Finally, it is necessary to measure the impact of the use of social networks on the economic results of marketing. To this end, the Marketing Science Institute establishes that the analysis should include the evaluation of the impact of marketing programs on the financial performance of organizations, the use of ROI, the valuation of intangibles such as Brand Equity or Customer Equity, as well as the relationship with clients such as awareness or customer loyalty, and the evaluation of the effect of advertising on sales effectiveness ${ }^{23-24}$.

\section{Conclusion}

The arrival of social networks on the business scene has been a phenomenon of enormous proportions. The most representative changes are to be found in the dynamics that have arrived in the economic scenarios, demanding, among other things, greater interaction between the parties of interest. In this way, it is now possible to do business regardless of distance, characteristics, time and space. However, this new orientation for business marketing, the demand for followup and high commitment on the part of the businessperson, as stated by researchers in the area, must move quickly and intelligently to achieve the changes that are necessary. On the other hand, aspects such as the training of the personnel of organizations is a vital component, since as suggested by studies, human resources must have the tools and resources to meet the requirements of internal and external customers, 
only in this way can constant growth be guaranteed, generating profits for companies. In Colombia, digital marketing is growing, so well managed social networks can be a competitive and differentiating factor for companies of all sizes.

\section{References}

1. Confederacion de Camaras de Comercio (Confecamaras). Analisis economico para la cooperacion y la competitividad, Cuadernos de analisis economico. 2011.

2. Gutierrez-Leefmans C, Nava-Rogel R. Mercadotecnia digital y las peque-as y medianas empresas: revision de la literatura. Revista Venezolana de Informacion, Tecnologia y Conocimiento. 2016; 13(1):45-61.

3. Shen G. Effective marketing communication via social networking site: The moderating role of the social tie. Journal of Business Research. 2016; 69(6):2265-70. Crossref.

4. Ashley C, Tracy T. Creative strategies in social media marketing: An exploratory study of branded social content and consumer engagement. Psychology \& Marketing. 2015; 32(1):15-27. Crossref.

5. Qiuju L, Dixi Z. Using social network analysis to explain communication characteristics of travel-related electronic word-of-mouth on social networking sites. Tourism Management. 2015; 46:274-82. Crossref.

6. Kerpen D. Likeable Social Media, Revised and Expanded: How to Delight Your Customers, create an Irresistible Brand, and Be Amazing on Facebook, Twitter, LinkedIn, Instagram, Pinterest, and More. McGraw-Hill. 2015. PMid:26266836.

7. Taylor JS, Robert B, De Vault M. Introduction to qualitative research methods: A guidebook and resource. John Wiley \& Sons. 2015; p. 1-416.

8. Lewis S. Qualitative inquiry and research design: Choosing among five approaches. Health promotion practice. 2015; 16(4):473-5. Crossref.

9. Mc Cusker K, Gunaydin S. Research using qualitative, quantitative or mixed methods and choice based on the research. Perfusion. 2015; 30(7):537-42. Crossref. PMid:25378417.

10. Andrade D. Estrategias de marketing digital en la promocion de Marca Ciudad. Revista EAN. 2016; p. 59-72. PMid:27706375 PMCid:PMC5068963.
11. Mulford M, Vergara L, Plata D. Tienda virtual: social market Colombia. Multiciencias. 2014; p. 268-75.

12. Lange W, Elliot D, Statia A. Understanding the Role of Social Media in Destination Marketing. Tourismos: An International Multidisciplinary Journal of Tourism. 2012; p. 193-211.

13. Mojica D, Josias D. Administrative function in the era of ICTs. Revista Lasallista de Investigacion. 2015; 12(2):139-51.

14. Constantinides E. Foundations of Social Media Marketing. Procedia - Social and Behavioral Sciences. 2014; p. 40-57. Crossref.

15. De Vries Gensler L, Leeflang P. Popularity of Brand Posts on Brand Fan Pages: An Investigation of the Effects of Social Media Marketing. Journal of Interactive Marketing. 2012; p. 83-91.

16. Erdogmus I, Cicek M. The impact of social media marketing on brand loyalty. Procedia - Social and Behavioral Sciences. 2012; 58:1353-60. Crossref.

17. Shih C. The Facebook era: Tapping online social networks to market, sell, and innovate. Pearson Education. 2010; p. 1-368. PMCid:PMC2818641.

18. Hays S, Page S, Buhalis D. Social media as a destination marketing tool: its use by national tourism organisations. Current Issues in Tourism. 2013; p. 211-39. Crossref.

19. Berthon P, Pitt L, Plangger K, Shapiro D. Marketing meets Web 2.0, social media, and creative consumers: Implications for international marketing strategy. Business Horizons. 2012; p. 261-71. Crossref.

20. Dahnil M, Marzuki K, Langgat J, Fabeil N. Factors Influencing SMEs Adoption of Social Media Marketing. Procedia - Social and Behavioral Sciences. 2014; p. 119-26. Crossref.

21. Bolotaeva V, Cata T. Marketing Opportunities with Social Networks. Journal of Internet Social Networking and Virtual Communities. 2011; p. 1-8.

22. Boston Consulting Group. Enabling Big Data: Building the Capabilities that really matter. 2014; p. 1-16.

23. Novoa A, Sabogal M, Vargas C. Estimacion de las relaciones entre la inversion en medios digitales y las variables financieras de la empresa: una aproximacion para Colombia. Revista EAN. 2016; p. 12-25.

24. Niebles-Nu-ez W, Hernandez-Palma H, Cardona-Arbelaez D. Gestion tecnologica del conocimiento: herramienta moderna para la gerencia de instituciones educativas. Revista de Investigacion, Desarrollo e Innovacion. 2016; 7(1):25-36. Crossref. 